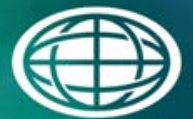

Savannah River

National Laboratory ${ }^{m}$

OPERATED BY SAVANNAH RIVER NUCLEAR SOLUTIONS

\title{
Results from the Salt Disposition Project (SDP) Next Generation Solvent (NGS) Demonstration Plan
}

T. B. Peters

F. F. Fondeur

K. M. L. Taylor-Pashow

April 2014

SRNL-STI-2014-00101, Revision 0 


\section{DISCLAIMER}

This work was prepared under an agreement with and funded by the U.S. Government. Neither the U.S. Government or its employees, nor any of its contractors, subcontractors or their employees, makes any express or implied:

1. warranty or assumes any legal liability for the accuracy, completeness, or for the use or results of such use of any information, product, or process disclosed; or

2. representation that such use or results of such use would not infringe privately owned rights; or

3. endorsement or recommendation of any specifically identified commercial product, process, or service.

Any views and opinions of authors expressed in this work do not necessarily state or reflect those of the United States Government, or its contractors, or subcontractors.

\section{Printed in the United States of America \\ Prepared for U.S. Department of Energy}




\section{Results from the Salt Disposition Project (SDP) Next Generation Solvent (NGS) Demonstration Plan}

T. B. Peters

F. F. Fondeur

K. M. L. Taylor-Pashow

April 2014

Prepared for the U.S. Department of Energy under contract number DE-AC09-08SR22470.

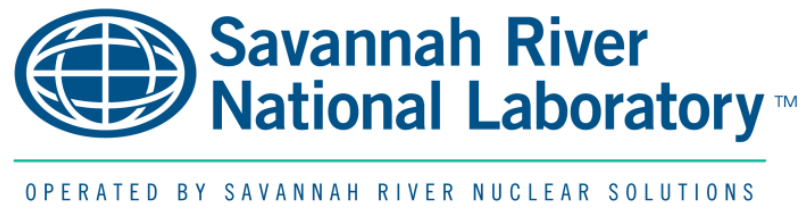




\section{REVIEWS AND APPROVALS}

\section{AUTHORS:}

T. B. Peters, Author, SRNL/ACP

Date

F. F. Fondeur, Co-author, SRNL/SASP

Date

K. M. L. Taylor-Pashow, Co-author, SRNL/SASP

Date

TECHNICAL REVIEW:

C. A. Nash, SRNL/ACP, Reviewed per E7 2.60

Date

\section{APPROVAL:}

F. M. Pennebaker, SRNL/ACP Manager

Date

S. L. Marra, Manager

Date

Environmental \& Chemical Process Technology Research Programs

D. J. Martin, Manager

Date

H Tank Farm Engineering 


\section{EXECUTIVE SUMMARY}

Strip Effluent Hold Tank (SEHT), Decontaminated Salt Solution Hold Tank (DSSHT), Caustic Wash Tank (CWT) and Solvent Hold Tank (SHT) samples were taken throughout the Next Generation Solvent (NGS) Demonstration Plan. These samples were analyzed and the results are reported.

- SHT: The solvent behaved as expected, with no bulk changes in the composition over time, with the exception of the TOA and TiDG. The TiDG depletion is higher than expected, and consideration must be taken on the required rate of replenishment. Monthly sampling of the SHT is warranted. If possible, additional SHT samples for TiDG analysis (only) would help SRNL refine the TiDG degradation model.

- CWT: The CWT samples show the expected behavior in terms of bulk chemistry. The ${ }^{137} \mathrm{Cs}$ deposited into the CWT varies somewhat, but generally appears to be lower than during operations with the BOBCalix solvent. While a few minor organic components were noted to be present in the Preliminary sample, at this time these are thought to be artifacts of the sample preparation or may be due to the preceding solvent superwash.

- DSSHT: The DSSHT samples show the predicted bulk chemistry, although they point towards significant dilution at the front end of the Demonstration. The ${ }^{137} \mathrm{Cs}$ levels in the DSSHT are much lower than during the BOBCalix operations, which is the expected observation.

- SEHT: The SEHT samples represent the most different output of all four of the outputs from MCU. While the bulk chemistry is as expected, something is causing the $\mathrm{pH}$ of the SEHT to be higher than what would be predicted from a pure stream of $0.01 \mathrm{M}$ boric acid. There are several possible different reasons for this, and SRNL is in the process of investigating. Other than the $\mathrm{pH}$ issue, the SEHT is as predicted.

In summary, the NGS Demonstration Plan samples indicate that the MCU system, with the Blend Solvent, is operating as expected. The only issue of concern regards the $\mathrm{pH}$ of the SEHT, and SRNL is in the process of investigating this. SRNL results support the transition to routine operations. 


\section{TABLE OF CONTENTS}

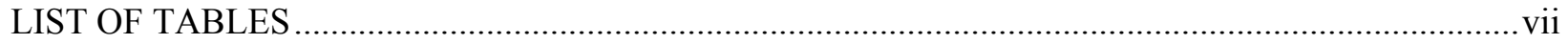

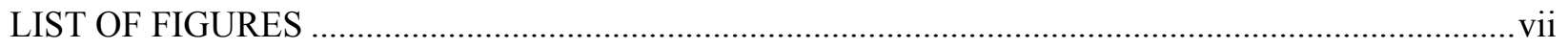

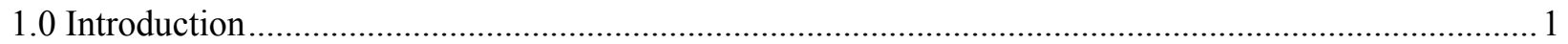

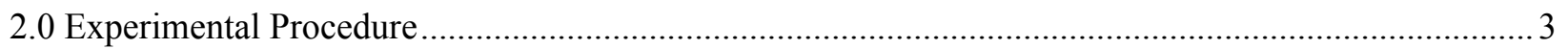

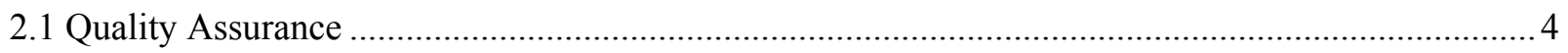

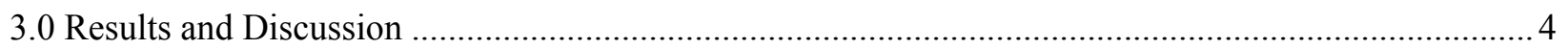

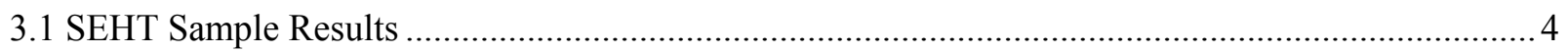

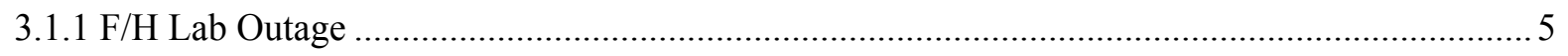

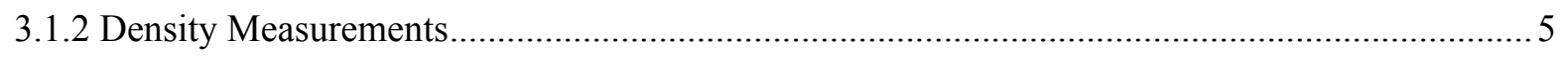

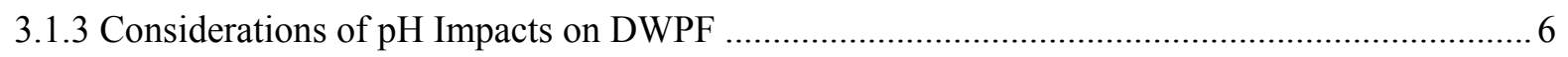

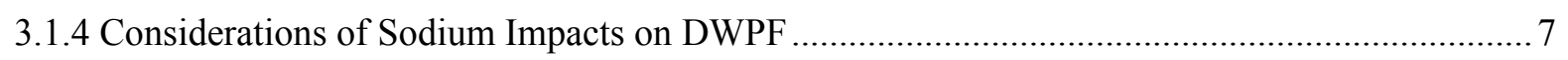

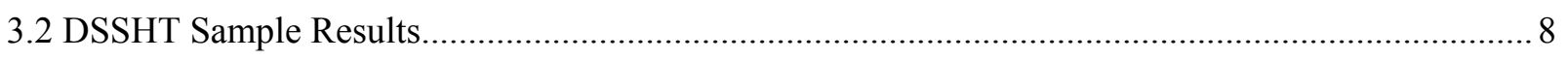

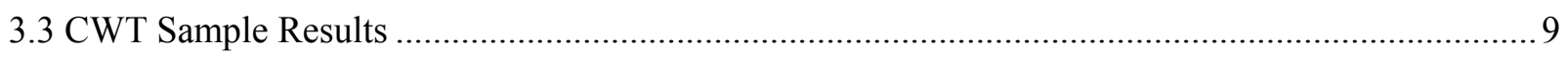

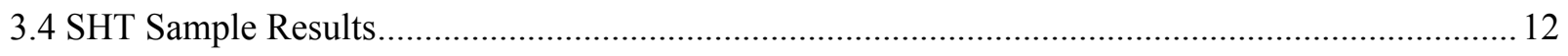

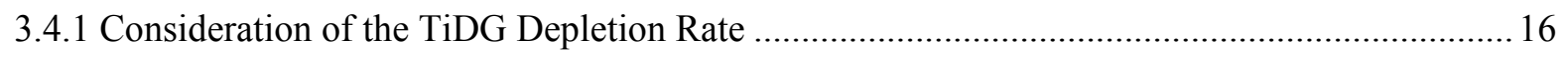

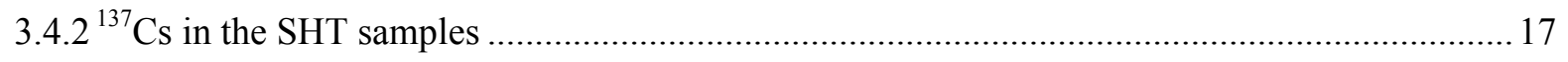

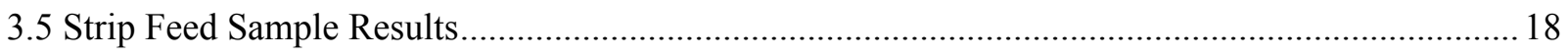

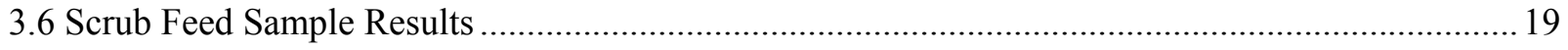

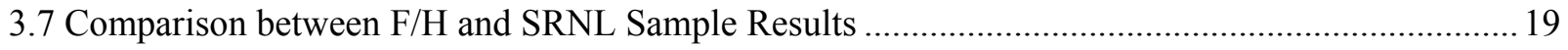

3.8 Brief Discussion of the Decontamination and Concentration Factors ….......................................2 21

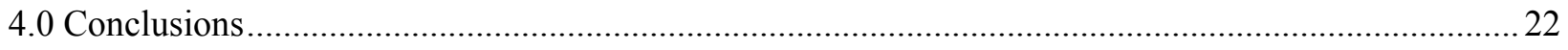

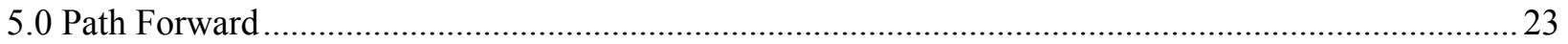




\section{LIST OF TABLES}

Table 1. Nominal Component Concentration in the Three Solvents ….................................................. 1

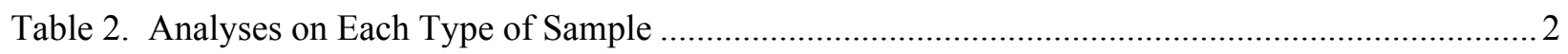

Table 3. Operating Conditions for Different Samples ......................................................................... 3

Table 4. Radiochemical Results for the SEHT Samples................................................................... 4

Table 5. Isopar ${ }^{\mathrm{TM}}$ L Results From SEHT Samples …....................................................................... 5

Table 6. Density Measurements of the SEHT Samples …....................................................................... 5

Table 7. pH Results for Demonstration Plan SEHT Samples ................................................................ 6

Table 8. TIC/TOC Measurements of Selected SEHT Samples ......................................................... 6

Table 9. Average Sodium Content of Previous Salt Batch 4, 5, and 6 ................................................ 7

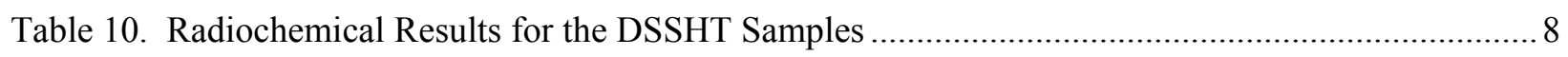

Table 11. Selected Non-Radiochemical Results for DSSHT Samples ................................................... 9

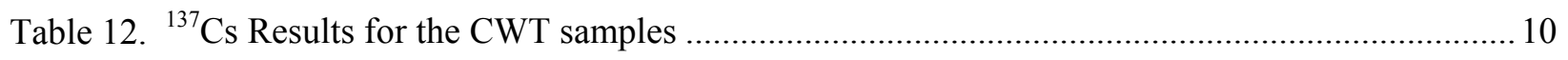

Table 13. Selected Non-Radiochemical Analyses on CWT Samples ...................................................... 11

Table 14. SVOA Analysis of the Preliminary CWT Sample .................................................................... 12

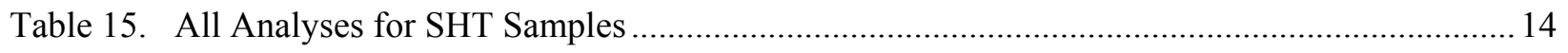

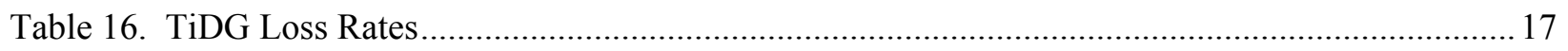

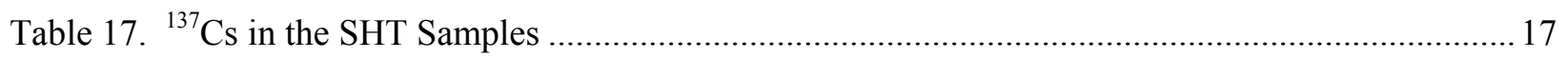

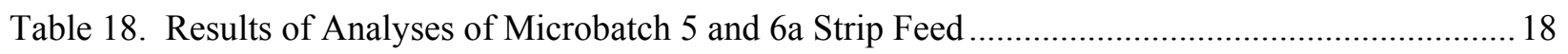

Table 19. Results of Analyses of Microbatch 6c Scrub Feed ................................................................ 19

Table 20. Comparison of ${ }^{137} \mathrm{Cs}$ Results between SRNL and F/H Lab .................................................20

Table 21. Free Hydroxide Results for Duplicate SRNL and F/H Samples........................................... 20

Table 22. DF and CF Values for Demonstration Plan Samples......................................................... 21

\section{LIST OF FIGURES}

Figure 1. Concentration Factor over the Range of Samples 22 


\section{LIST OF ABBREVIATIONS}

$\begin{array}{ll}\text { ARP } & \text { Actinide Removal Process } \\ \text { CF } & \text { Concentration Factor } \\ \text { CWT } & \text { Caustic Wash Tank } \\ \text { DF } & \text { Decontamination Factor } \\ \text { DSS } & \text { Decontaminated Salt Solution } \\ \text { DSSHT } & \text { Decontaminated Salt Solution Hold Tank } \\ \text { HPLC } & \text { High Performance Liquid Chromatography } \\ \text { IC } & \text { Ion Chromatography } \\ \text { ICPES } & \text { Inductively-Coupled Plasma Emission Spectroscopy } \\ \text { ICPMS } & \text { Inductively-Coupled Plasma Mass Spectroscopy } \\ \text { MCU } & \text { Modular Caustic-Side Solvent Extraction Unit } \\ \text { MST } & \text { monosodium titanate } \\ \text { PuTTa } & \text { Plutonium thenoyl trifluoroacetone scintillation } \\ \text { RSD } & \text { Relative standard deviation } \\ \text { SE } & \text { Strip Effluent } \\ \text { SEHT } & \text { Strip Effluent Hold Tank } \\ \text { SHT } & \text { Solvent Hold Tank } \\ \text { SRNL } & \text { Savannah River National Laboratory } \\ \text { SVOA } & \text { Semi-Volatile Organic Analysis } \\ \text { TIC/TOC } & \text { Total Inorganic Carbon/Total Organic Carbon } \\ \text { TOA } & \text { trioctylamine } \\ \text { TiDG } & \text { N, N', N'- tris(isotridecyl)guanidine } \\ \end{array}$




\subsection{Introduction}

The MCU process previously operated with a four component solvent which removes cesium from clarified salt solution. The previous solvent, designated BOBCalixC6 Based Solvent (or "BOB Solvent"), is comprised of BOBCalixC6 (extractant), trioctylamine (TOA) (suppressor), Cs-7SB (modifier), and Isopar ${ }^{\mathrm{TM}} \mathrm{L}$ (diluent). NGS utilizes a new extractant and suppressor in MCU; it is a four component mixture comprised of MaxCalix (extractant), N, N', N' - tris(isotridecyl)guanidine (TiDG, the suppressor), Cs7SB (modifier), and Isopar ${ }^{\mathrm{TM}} \mathrm{L}$ (diluent). The NGS solvent components were introduced to the MCU system in a "concentrate" and blended with the residual volume (95 gallons) of BOBCalixC6 Based Solvent to create the NGS Blend. ${ }^{i}$

Table 1. Nominal Component Concentration in the Three Solvents

\begin{tabular}{|c|c|c|c|}
\hline \multirow{2}{*}{ Component } & \multicolumn{3}{|c|}{ Nominal component concentration in the three Solvents $(\mathrm{mg} / \mathrm{L})$} \\
\hline & BOB Solvent & NGS Blend & NGS \\
\hline BOBCalix & 8050 & 4030 & NA \\
\hline MAXCalix & NA & 44400 & 47800 \\
\hline Modifier & 254000 & 169000 & 169000 \\
\hline TOA & 1060 & 530 & NA \\
\hline TiDG & NA & 1550 & 1550 \\
\hline Isopar ${ }^{\mathrm{TM}} \mathrm{L}$ & balance & balance & balance \\
\hline
\end{tabular}

After NGS implementation with the NGS Blend, all solvent additions will consist of only NGS constituents. Therefore, the operating solvent will gradually approach the final "NGS" concentrations indicated in Table 1. The NGS Blend composition in Table 1 is a projected estimate that assumes the residual BOBCalix solvent was mixed with an equal volume of concentrate. The actual component concentrations in the Blend solvent depends on the volume of the operating heel of solvent at time of transition and thus, may vary slightly from the estimated composition.

In order to transition from the BOB Solvent to the NGS Blend, the MCU facility is undergoing a period of deliberate operations deemed the NGS Demonstration. A Preliminary sample and six micro-batches $(1,2 \mathrm{a} / 2,3,4,5$, and $6 \mathrm{a} / 6 \mathrm{~b} / 6 \mathrm{c})$ of clarified salt solution were processed during the Demonstration Period. Each microbatch was operated at a prescribed flow rate until the DSSHT was full. During the Demonstration Period the MCU was operated under a sample-and-hold strategy. After each microbatch, samples were taken from key process vessels; the Strip Effluent Hold Tank (SEHT), the Decontaminated Salt Solution Hold Tank (DSSHT), the Solvent Hold Tank (SHT) and the Caustic Wash Tank (CWT). In addition, samples from the scrub feed tank $(0.025 \mathrm{M}$ $\mathrm{NaOH})$ and strip feed tank ( $0.01 \mathrm{M}$ boric acid) were analyzed as needed. The analyses performed on each sample varied depending on the particular sample (see Table 2). ${ }^{\text {ii }}$ Some samples were sent to SRNL and some were sent to F/H lab. Results from the F/H 
lab samples are not generally reported in this document, unless otherwise required for comparison.

Table 2. Analyses on Each Type of Sample

\begin{tabular}{|c|c|c|c|c|}
\hline \multirow{2}{*}{ Sample } & \multicolumn{4}{|c|}{ Types of Analyses for Each Sample } \\
\hline & SEHT & DSSHT & CWT & SHT \\
\hline Preliminary & 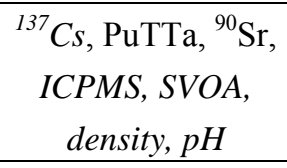 & 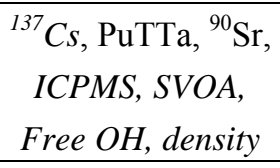 & $\begin{array}{c}{ }^{137} \mathrm{Cs}, \mathrm{SVOA}, \\
\mathrm{HPLC}, \mathrm{pH}\end{array}$ & $\begin{array}{c}\text { solvent, }{ }^{137} \mathrm{Cs}, \\
\text { density }\end{array}$ \\
\hline Microbatch 1 & $\begin{array}{c}{ }^{137} \mathrm{Cs}, \mathrm{PuTTa},{ }^{90} \mathrm{Sr}, \\
\text { ICPES, SVOA, } \\
\text { density, } p H\end{array}$ & $\begin{array}{c}{ }^{137} \mathrm{Cs}, \text { SVOA, Free } \\
\mathrm{OH} \text {, density }\end{array}$ & $\begin{array}{c}{ }^{137} \mathrm{Cs}, \mathrm{pH}, \text { ICPES, } \\
\text { SVOA, density }\end{array}$ & $\begin{array}{c}\text { solvent, }{ }^{137} \mathrm{Cs} \text {, } \\
\text { density }\end{array}$ \\
\hline $\begin{array}{l}\text { Microbatch } 2 \\
\text { (Received two sets of } \\
\text { samples, deemed 2a } \\
\text { and 2) }\end{array}$ & $\begin{array}{c}{ }^{137} \text { Cs, ICPES, } \\
\text { SVOA, density, } p H\end{array}$ & $\begin{array}{c}{ }^{137} \mathrm{Cs}, \text { SVOA, Free } \\
\mathrm{OH} \text {, density }\end{array}$ & $\begin{array}{c}{ }^{137} \mathrm{Cs}, \mathrm{pH}, \text { ICPES, } \\
\text { SVOA, density }\end{array}$ & $\begin{array}{c}\text { solvent, }{ }^{137} \mathrm{Cs}, \\
\text { density }\end{array}$ \\
\hline Microbatch 3 & $\begin{array}{c}{ }^{137} \text { Cs, ICPES, } \\
\text { SVOA, density, } p H\end{array}$ & $\begin{array}{c}{ }^{137} \mathrm{Cs}, \text { SVOA, Free } \\
\mathrm{OH} \text {, density }\end{array}$ & $\begin{array}{c}{ }^{137} \mathrm{Cs}, \mathrm{pH}, \text { ICPES, } \\
\text { SVOA, density }\end{array}$ & $\begin{array}{c}\text { solvent, }{ }^{137} \mathrm{Cs}, \\
\text { density }\end{array}$ \\
\hline Microbatch 4 & $\begin{array}{c}{ }^{137} \text { Cs, ICPES, } \\
\text { SVOA, density, } p H\end{array}$ & $\begin{array}{c}{ }^{137} \mathrm{Cs}, \text { SVOA, Free } \\
\mathrm{OH} \text {, density }\end{array}$ & $\begin{array}{c}{ }^{137} \mathrm{Cs}, \mathrm{pH}, \mathrm{ICPES}, \\
\text { SVOA, density, } \\
\text { Free } \mathrm{OH} \\
\end{array}$ & $\begin{array}{c}\text { solvent, }{ }^{137} \mathrm{Cs}, \\
\text { density }\end{array}$ \\
\hline Microbatch 5 & $\begin{array}{c}{ }^{137} \mathrm{Cs}, \mathrm{ICPES}, \\
\text { SVOA, density, } \\
\text { pH, TIC/TOC, } \\
\text { carbonate }\end{array}$ & $\begin{array}{c}{ }^{137} \mathrm{Cs}, \text { SVOA, Free } \\
\mathrm{OH}, \text { density }\end{array}$ & $\begin{array}{c}{ }^{137} \mathrm{Cs}, \mathrm{pH}, \text { ICPES, } \\
\text { SVOA, density, } \\
\text { Free } \mathrm{OH}\end{array}$ & $\begin{array}{c}\text { solvent, }{ }^{137} \mathrm{Cs}, \\
\text { density }\end{array}$ \\
\hline Microbatch 6a & $\begin{array}{c}{ }^{137} \mathrm{Cs}, \text { ICPES, } \\
\text { SVOA, density, } \\
\text { TIC/TOC, } \\
\text { carbonate, } p H \\
\end{array}$ & $\begin{array}{c}{ }^{137} \mathrm{Cs}, \mathrm{SVOA}, \text { Free } \\
\mathrm{OH} \text {, density }\end{array}$ & No sample & $\begin{array}{c}\text { solvent, }{ }^{137} \mathrm{Cs}, \\
\text { density }\end{array}$ \\
\hline Microbatch $6 \mathrm{~b}$ & $\begin{array}{c}{ }^{137} \mathrm{Cs}, \mathrm{ICPES}, \\
\text { SVOA, density, } \\
\text { TIC/TOC, } \\
\text { carbonate, } p H \\
\end{array}$ & $\begin{array}{c}{ }^{137} \mathrm{Cs}, \text { SVOA, Free } \\
\mathrm{OH} \text {, density }\end{array}$ & ${ }^{137} \mathrm{Cs}, \mathrm{pH}$ & $\begin{array}{c}\text { solvent, }{ }^{137} \mathrm{Cs}, \\
\text { density }\end{array}$ \\
\hline Microbatch 6c & $\begin{array}{c}{ }^{137} \mathrm{Cs}, \mathrm{ICPES}, \\
\text { SVOA, density, } \\
\text { TIC/TOC, } \\
\text { carbonate, } p H\end{array}$ & $\begin{array}{c}{ }^{137} \mathrm{Cs}, \text { SVOA, Free } \\
\mathrm{OH}, \text { density }\end{array}$ & ${ }^{137} \mathrm{Cs}, \mathrm{pH}$ & $\begin{array}{c}\text { solvent, }{ }^{137} \mathrm{Cs}, \\
\text { density }\end{array}$ \\
\hline
\end{tabular}

Samples in italic were run at $\mathrm{F} / \mathrm{H}$ and not necessarily reported in this document. "Solvent" type analysis means separate analyses were run for Isopar"TM (Semi-Volatile Organic Analysis - SVOA), Modifier (High performance Liquid Chromatography HPLC, SVOA), Trioctylamine - TOA, BOB/MaxCalix (HPLC) and TiDG (titration). 
In switching to the NGS, MCU also implemented the NGS flow sheet, which changed some process chemistry and operating parameters. Therefore, the hydraulic stability and the solvent efficiency was evaluated at the flow rates seen in Table 3.

Table 3. Operating Conditions for Different Samples

\begin{tabular}{|c|c|}
\hline Sample & Salt Solution Feed Rate (gpm) \\
\hline Preliminary & NA \\
\hline Microbatch 1 & 4 \\
\hline Microbatch 2a/2 & 6 \\
\hline Microbatch 3 & 8 \\
\hline Microbatch 4 & 7.5 \\
\hline Microbatch 5 & 8.5 \\
\hline Microbatch 6a & 6 \\
\hline Microbatch 6b & 5 \\
\hline Microbatch 6c & 8.5 \\
\hline
\end{tabular}

During Microbatch 2, a process upset caused by an extraction contactor spinning in reverse caused MCU to be shutdown prematurely. A complete set of process vessel samples (i.e. "microbatch 2 samples") were pulled to confirm the integrity of the corresponding tank material. Upon correction of the mechanical issue MCU was restarted to finish the microbatch 2 run and then resampled per standard NGS Demonstration requirements. During Microbatch 5 and Microbatch 6a additional analysis was requested on the DSSHT and SEHT samples as a results of an unexpected outage at $\mathrm{F} / \mathrm{H}$ lab.

MCU was required to complete five micro-batches at prescribed flow rates per the NGS Demonstration Plan. Due to mechanical issues experienced during Microbatch 2, MCU was expected to stop sampling after the sixth microbatch. However, due to the increased strip feed flow rate issue experienced in Microbatch 6, coupled with the required startup time to reach the last prescribed flow rate $(8.5 \mathrm{GPM})$, the decision was made to restart the micro-batch with only the DSSHT heel. The complete working volume of the DSSHT would allow for more sufficient demonstration time at $8.5 \mathrm{GPM}$; therefore, this series was labeled as Microbatch $6 \mathrm{a} / 6 \mathrm{~b} / 6 \mathrm{c}$.

\subsection{Experimental Procedure}

The samples arriving at SRNL were contained in 10-mL P-nut vials. SEHT samples were delivered in doorstops for shielding purposes. SHT samples were delivered in a new sample holder. The CWT and DSSHT samples were delivered in thief holders. 
Samples of the scrub and strip feeds were delivered in $250 \mathrm{~mL}$ poly bottles. All samples were sent for analysis without dilution or filtration. $\mathrm{pH}$ measurements were provided by

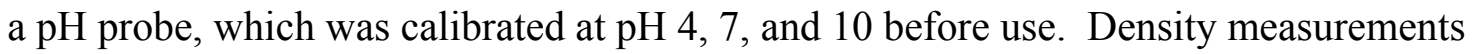
used a calibrated $2 \mathrm{~mL}$ density tube.

\subsection{Quality Assurance}

Requirements for performing reviews of technical reports and the extent of review are established in manual E7 2.60. SRNL documents the extent and type of review using the SRNL Technical Report Design Checklist contained in WSRC-IM-2002-00011, Rev 2.

\subsection{Results and Discussion}

\subsection{SEHT Sample Results}

Most of the SEHT sample analyses were performed at F/H lab. SRNL SEHT analytical results are reported in Tables $4-6$. The ${ }^{137} \mathrm{Cs}$ activity and the Isopar L concentration are especially of interest in demonstrating NGS processability. The $\mathrm{pH}$ probe and density measurements were performed in the Shielded Cells. For those SE samples sent for SVOA analysis, the samples were prepared in the Shielded Cells as described in section 3.1.1.

The ${ }^{137} \mathrm{Cs}$ activity and other radioisotope results are reported in Table 4 .

Table 4. Radiochemical Results for the SEHT Samples

\begin{tabular}{|c|c|c|c|}
\hline \multirow{2}{*}{ Sample } & \multicolumn{3}{|c|}{$\mathrm{dpm} / \mathrm{mL}$} \\
\cline { 2 - 4 } & ${ }^{\mathbf{1 3 7}} \mathbf{C s}$ & ${ }^{\mathbf{2 3 8}} \mathbf{P u}$ & ${ }^{\mathbf{9 0}} \mathbf{S r}$ \\
\hline Prelim & NA & $<6.74$ & $5.35 \mathrm{E}+01(31.1 \%)$ \\
\hline Microbatch 1 & $1.55 \mathrm{E}+08$ & $<6.07$ & $6.49 \mathrm{E}+01(25.7 \%)$ \\
\hline Microbatch 2a/2 & NA & NA & NA \\
\hline Microbatch 3 & NA & NA & NA \\
\hline Microbatch 4 & NA & NA & NA \\
\hline Microbatch 5 & $1.74 \mathrm{E}+09$ & NA & NA \\
\hline Microbatch 6a & $1.65 \mathrm{E}+09$ & NA & NA \\
\hline Microbatch 6b & $1.09 \mathrm{E}+09$ & NA & NA \\
\hline Microbatch 6c & NA & NA & $4.14 \mathrm{E}+05$ \\
\hline SB6 Feed & $1.30 \mathrm{E}+08$ & $2.91 \mathrm{E}+04$ & \\
\hline
\end{tabular}

The analytical uncertainty on the ${ }^{137} \mathrm{Cs}$ samples is $5 \%$. Otherwise, the analytical uncertainty is listed in parentheses next to the reported value. 
The Pu results are very comparable to previous Salt Batch 6 routine samples. ${ }^{\text {iii }}$ This is not surprising given that the change in solvent should have no effect on the $\mathrm{Pu}$ in the SE. The prelim ${ }^{90} \mathrm{Sr}$ value is previously reported, ${ }^{\text {iii }}$ and the microbatch 1 sample is comparable. The ${ }^{137} \mathrm{Cs}$ is also roughly comparable to previously reported values, which may seem surprising given the expected increased performance in ${ }^{137} \mathrm{Cs}$ removal of the NGS Blend solvent. However, the reader must recall that the increased performance (decontamination factor) is manifested in the further decline in the DSSHT ${ }^{137} \mathrm{Cs}$ values (compared to the BOBCalix solvent). Those values are numerically small compared to the large SEHT ${ }^{137}$ Cs values, and so a large increase in the SEHT ${ }^{137}$ Cs values was not predicted.

\subsubsection{F/H Lab Outage}

At two points during the Demonstration Plan, $\mathrm{F} / \mathrm{H}$ lab experienced an outage. SRNL was able to analyze the SEHT samples during that time, which would normally have been sent to $\mathrm{F} / \mathrm{H}$ lab. In the shielded cells, the samples were prepared by using $3 \mathrm{~mL}$ of hexane to extract the organic compounds from the $10 \mathrm{~mL}$ samples. These $3 \mathrm{~mL}$ SEHT extracts were analyzed for Isopar ${ }^{\mathrm{TM}} \mathrm{L}$ content. The results are reported in Table 5.

\section{Table 5. Isopar ${ }^{\mathrm{TM}} \mathrm{L}$ Results From SEHT Samples}

\begin{tabular}{|c|c|}
\hline Sample & Isopar $^{\mathrm{TM}} \mathbf{L} \mathbf{( m g / L )}$ \\
\hline Microbatch 5 & $<7$ \\
\hline Microbatch 6a & $<7$ \\
\hline
\end{tabular}

In both cases, less than detectable amounts of Isopar ${ }^{\mathrm{TM}} \mathrm{L}$ were measured.

\subsubsection{Density Measurements}

The densities of selected SEHT samples were measured. See Table 6.

Table 6. Density Measurements of the SEHT Samples

\begin{tabular}{|c|c|}
\hline Sample & Density $(\mathbf{g} / \mathbf{m L})$ \\
\hline Microbatch 5 & $1.00\left(25^{\circ} \mathrm{C}\right)$ \\
\hline Microbatch 6a & $0.994\left(13.4^{\circ} \mathrm{C}\right)$ \\
\hline Microbatch 6b & $0.964\left(19^{\circ} \mathrm{C}\right)$ \\
\hline Microbatch 6c & $0.992\left(15.1^{\circ} \mathrm{C}\right)$ \\
\hline
\end{tabular}

The density of pure $0.01 \mathrm{M}$ boric acid should be $\sim 1.00 \mathrm{~g} / \mathrm{mL}$. The measured deviations from 1.00 are indicative of the difficulty in measuring density in the shielded cells. 


\subsubsection{Considerations of $p H$ Impacts on DWPF}

The $\mathrm{SE}$ is required to have a $\mathrm{pH}$ between 2 and $8 .^{\mathrm{iv}}$ However, starting with the Microbatch 4 samples, all the samples were measured to have a $\mathrm{pH}$ higher than 8 , with one as high as 8.7. See Table 7.

Table 7. pH Results for Demonstration Plan SEHT Samples

\begin{tabular}{|c|c|}
\hline sample & pH \\
\hline Microbatch 1 & 6.8 \\
\hline Microbatch 2 & 7.7 \\
\hline Microbatch 3 & 6.4 \\
\hline Microbatch 4 & 8.3 \\
\hline Microbatch 5 & 8.7 \\
\hline Microbatch 6a & 8.6 \\
\hline Microbatch 6b & 8.3 \\
\hline Microbatch 6c & 8.2 \\
\hline
\end{tabular}

The uncertainty of the SRNL $\mathrm{pH}$ probe is $0.1 \mathrm{pH}$ units and $1.6 \%$ for the $\mathrm{F} / \mathrm{H}$ lab probe.

The $\mathrm{pH}$ values were measured at $\mathrm{F} / \mathrm{H}$ lab (except for Microbatch 5), but reported here for continuity. $\mathrm{F} / \mathrm{H}$ lab used a $\mathrm{pH}$ probe for the measurement. In addition, SRNL measured the $\mathrm{pH}$ of the Microbatch $6 \mathrm{c}$ sample by $\mathrm{pH}$ probe and also found the results to be 8.3.

This triggered additional work scope at SRNL in order to determine the reason for the elevated $\mathrm{pH}$ results, and the effect it would have on DWPF. First, SRNL studied the $\mathrm{pH}$ impacts and issued two white papers on the subject. ${ }^{\mathrm{v} v \mathrm{vi}}$ Second, SRNL is following a task technical request ${ }^{\text {vii }}$ to cover future experiments that investigate this issue. Finally, the customer and SRNL agreed to additional sample analyses of selected SEHT microbatch samples coming to SRNL. Microbatch 5, 6a, 6b and 6c SEHT samples were analyzed by Total Inorganic Carbon/Total Organic Carbon (TIC/TOC). See Table 8.

Table 8. TIC/TOC Measurements of Selected SEHT Samples

\begin{tabular}{|c|c|c|}
\hline Sample & $\begin{array}{c}\text { Total Inorganic } \\
\text { Carbon (mg/L) }\end{array}$ & $\begin{array}{c}\text { Total Organic } \\
\text { Carbon (mg/L) }\end{array}$ \\
\hline Microbatch 5 & 26.3 & 47.1 \\
\hline Microbatch 6a & 21.6 & 49.6 \\
\hline Microbatch 6b & 27.8 & 50.5 \\
\hline Microbatch 6c & 34.4 & 50.6 \\
\hline
\end{tabular}


The analytical uncertainties of the TIC/TOC measurements are 10\%. The Microbatch 5 result was previously reported. ${ }^{\text {viii }}$

The TIC result is considered to correspond to carbonate, and once the TIC results are converted to carbonate, would result in $0.0022,0.0018,0.0023$ and $0.0029 \mathrm{M}$ of carbonate, respectively for Microbatch 5, 6a, 6b, and 6c. This is perhaps coincidentally the same amount of base estimated to be required to titrate a solution of $0.01 \mathrm{M}$ boric acid

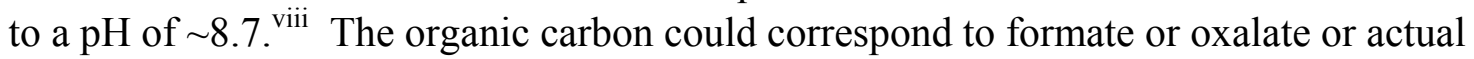
organic material.

Without corroboration with experimental data, it is difficult to say what precisely is causing the $\mathrm{pH}$ to be elevated past the theoretical value for $0.01 \mathrm{M}$ boric acid (5.7), a more in-depth discussion is provided in one of the previously completed white papers. ${ }^{\mathrm{v}}$

The Microbatch 5 and 6c Strip Feed samples were analyzed, and this is reported in a later section (see section 3.5). As a result of all of the additional work, the DWPF WAC was modified to accept a $\mathrm{pH}$ range of 2 to $11 .^{\text {ix }}$

\subsubsection{Considerations of Sodium Impacts on DWPF}

While the revision to the DWPF WAC provided relief of the elevated $\mathrm{pH}$ issues in the SEHT, the latest revision added a sodium concentration requirement. The SEHT samples must now contain $\leq 265 \mathrm{mg} / \mathrm{L}$ of sodium. While this sodium content issue is addressed in depth in the previously mentioned white paper, ${ }^{\mathrm{V}}$ it is still relevant to mention here since sodium results could be indicators of NGS process performance.

An examination of the last three Salt Batches (previous processing campaigns using the BOBCalix Solvent) SEHT samples show a consistent pattern of sodium content (Table 9).

\section{Table 9. Average Sodium Content of Previous Salt Batch 4, 5, and 6} SEHT Samples

\begin{tabular}{|c|c|}
\hline Salt Batch & Average Na Concentration (mg/L) \\
\hline 4 & 47.3 \\
\hline 5 & 61.7 \\
\hline 6 & 55.6 \\
\hline
\end{tabular}

The analytical uncertainty on the sodium measurements are $10 \%$. For the Demonstration Plan samples, Microbatch 5, 6a, 6b and 6c SEHT samples were analyzed for sodium content.* The average of all four microbatch results is $44.0 \mathrm{mg} / \mathrm{L}$. Even with the change

\footnotetext{
* Microbatch 1 was also analzyed for sodium content, but was discarded from this consideration due to the fact that this early in the demonstration plan, the processed feed was still heavily compromised by dilution.
} 
from the old solvent (Salt Batch 4, 5,6) to the new Blend solvent, there is little change in the sodium content. This implies that the increase on calixarene does not affect sodium uptake. Although it may be a coincidence, the sodium concentration in the SE ( 45 $\mathrm{mg} / \mathrm{L}$, or $\sim 0.002 \mathrm{M}$ ) is approximately the concentration of the carbonate in the same samples.

\subsection{DSSHT Sample Results}

While F/H lab performed most of the analyses on the DSSHT sample, SRNL performed several types of analyses on various samples. The most important analytes of the DSSHT samples were the ${ }^{137} \mathrm{Cs},{ }^{238} \mathrm{Pu}$, and ${ }^{90} \mathrm{Sr}$ activity and the Isopar ${ }^{\mathrm{TM}} \mathrm{L}$ concentration.

The radioisotope results are reported in Table 10 .

Table 10. Radiochemical Results for the DSSHT Samples

\begin{tabular}{|c|c|c|c|}
\hline \multirow{2}{*}{ Sample } & \multicolumn{3}{|c|}{$\mathrm{dpm} / \mathrm{mL}$} \\
\cline { 2 - 4 } & ${ }^{137} \mathbf{C s}$ & ${ }^{\mathbf{2 3 8}} \mathbf{P u}$ & ${ }^{\mathbf{9 0}} \mathbf{S r}$ \\
\hline Prelim & NA & $6.09 \mathrm{E}+02(5.52 \%)$ & $5.37 \mathrm{E}+03(14.1 \%)$ \\
\hline Microbatch 1 & $1.35 \mathrm{E}+06$ & $2.98 \mathrm{E}+03(6.00 \%)$ & $3.89 \mathrm{E}+03(9.56 \%)$ \\
\hline Microbatch 2a/2 & NA & NA & NA \\
\hline Microbatch 3 & NA & NA & NA \\
\hline Microbatch 4 & NA & NA & NA \\
\hline Microbatch 5 & $7.17 \mathrm{E}+04$ & NA & NA \\
\hline Microbatch 6a & $8.47 \mathrm{E}+04$ & NA & NA \\
\hline Microbatch 6b & NA & NA & NA \\
\hline Microbatch 6c & NA & NA & NA \\
\hline SB6 Feed & $1.30 \mathrm{E}+08$ & $2.91 \mathrm{E}+04$ & $4.14 \mathrm{E}+05$ \\
\hline
\end{tabular}

The analytical uncertainty on the ${ }^{137} \mathrm{Cs}$ measurements is $5 \%$. Otherwise, the analytical uncertainty is listed in parentheses next to the reported value.

The few ${ }^{238} \mathrm{Pu}$ and ${ }^{90} \mathrm{Sr}$ results for the DSSHT samples are similar to those previously reported results from routine Salt Batch 6 samples. ${ }^{\text {iii }}$ The ${ }^{137}$ Cs results show an overall decline from the beginning to the end. This is an indication that the Blend Solvent is performing in the expected manner. The higher extractant concentration is expressing itself as a lower ${ }^{137} \mathrm{Cs}$ activity in the DSSHT samples.

Across the spectrum of samples in the Demonstration Plan, various analyses were performed. Inductively Coupled Plasma Emission Spectroscopy (ICPES) analysis was performed on the Preliminary sample. An Ion Chromatography (IC) Anions analysis was 
performed on a Microbatch 1 sample. SVOA, density and Free Hydroxide measurements were performed on the Microbatch 5 and 6a samples. See Table 11.

Table 11. Selected Non-Radiochemical Results for DSSHT Samples

\begin{tabular}{|c|c|c|c|c|}
\hline Analyte & Prelim & Microbatch 1 & Microbatch 5 & Microbatch 6a \\
\hline Sodium $(\mathrm{mg} / \mathrm{L})$ & 105000 & NA & NA & NA \\
\hline Isopar $^{\mathrm{TM}} \mathrm{L}(\mathrm{mg} / \mathrm{L})$ & NA & NA & $<7$ & $<7$ \\
\hline Nitrate $(\mathrm{mg} / \mathrm{L})$ & NA & 68900 & NA & NA \\
\hline Nitrite $(\mathrm{mg} / \mathrm{L})$ & NA & 11000 & NA & NA \\
\hline Density $(\mathrm{g} / \mathrm{mL})$ & NA & NA & 1.25 & 1.25 \\
\hline Free $\mathrm{OH}(\mathrm{M})$ & NA & NA & 2.07 & 1.96 \\
\hline
\end{tabular}

The sodium, nitrate, nitrite, and Free $\mathrm{OH}$ measurements have an analytical uncertainty of $10 \%$. The Isopar ${ }^{\mathrm{TM}} \mathrm{L}$ measurement has an analytical uncertainty of $20 \%$. Density results from the average of replicate volumetric trials typically have a percentage standard deviation of $<1 \%$ between each value and the average.

The SVOA, density and Free Hydroxide measurements on the Microbatch 5 and 6a samples were performed as part of the $\mathrm{F} / \mathrm{H}$ lab outage mentioned in section 3.1.1. All of these results were as expected. SVOA was expected to be less than detectable, the density was expected to be $\sim 1.25 \mathrm{~g} / \mathrm{mL}$, and the Free Hydroxide was expected to be $\sim 2 \mathrm{M}$.

The other analyses were performed in order to examine the relative dilution the feed was experiencing. For example, the Preliminary sample gave a sodium result of $105000 \mathrm{mg} / \mathrm{L}$. The Macrobatch 6 feed was an average of $151000 \mathrm{mg} / \mathrm{L}$, indicating a significant dilution ( $\sim 30 \%$ dilution). For the Microbatch 1 sample, both the measured nitrate and nitrite were measured to be $\sim 50 \%$ of the Macrobatch 6 feed value. Early on in the demonstration plan, significant dilution of the feed material was occurring as a result of residual flush materials present in the hold tanks and decanters prior to the start of the NGS Demonstration.

\subsection{CWT Sample Results}

In theory, the caustic wash contactors serve to clean the solvent of any degradation products, such a sec-butyl-phenol. In reality, they also function as a scrub contactor, as the caustic wash $(0.03 \mathrm{M} \mathrm{NaOH})$ is very similar to the caustic scrub $(0.025 \mathrm{M})$. This also means that the stripped solvent, will deposit some ${ }^{137} \mathrm{Cs}$ activity into the spent caustic wash. The extent of the deposition of activity into the Caustic Wash Tank (CWT) has varied over the years. Previous CWT samples have varied from $\sim 1 \mathrm{E}+03 \mathrm{dpm} / \mathrm{mL}$ to 
$\sim 1 \mathrm{E}+06 \mathrm{dpm} / \mathrm{mL}^{\mathrm{x}}$ of ${ }^{137} \mathrm{Cs}$ activity. While microbatch sample 6a was not delivered to SRNL, the others were analyzed for ${ }^{137} \mathrm{Cs}$ content. The results are reported in Table 12.

Other than the Preliminary sample, the ${ }^{137} \mathrm{Cs}$ activities were all lower than previous CWT samples for the BOBCalix solvent. This could be an indication that the caustic wash is poorer at removing activity from the solvent, or that the stripped solvent has less activity to transfer to the caustic wash to begin with. Since the caustic scrub in the NGS or the Blend solvent in SRNL ESS testing removed non-trivial amounts of ${ }^{137} \mathrm{Cs}$, the latter reason is more probable. ${ }^{\mathrm{xi}}$

Table 12. ${ }^{137}$ Cs Results for the CWT samples

\begin{tabular}{|c|c|}
\hline Sample & $\left.{ }^{137} \mathbf{C s} \mathbf{( d p m} / \mathbf{m L}\right)$ \\
\hline Prelim & $5.28 \mathrm{E}+04$ \\
\hline Microbatch 1 & $6.62 \mathrm{E}+02$ \\
\hline Microbatch 2 & $7.67 \mathrm{E}+02$ \\
\hline Microbatch 3 & $8.60 \mathrm{E}+02$ \\
\hline Microbatch 4 & $1.22 \mathrm{E}+02(8.46 \%)$ \\
\hline Microbatch 5 & $5.65 \mathrm{E}+02$ \\
\hline Microbatch 6a & NA \\
\hline Microbatch 6b & $4.24 \mathrm{E}+02$ \\
\hline Microbatch 6c & $7.80 \mathrm{E}+02$ \\
\hline
\end{tabular}

The analytical uncertainty for all samples is $5 \%$, unless otherwise noted in parentheses next to the reported value.

In addition to the ${ }^{137} \mathrm{Cs}$ measurements, several other types of measurements were performed on various CWT samples, with the goal of monitoring the quality of the caustic wash. See Table 13. In these samples, $\mathrm{pH}$ was measured by $\mathrm{pH}$ paper and not $\mathrm{pH}$ probe. No organic or gel layers were seen during visual inspection of the CWT samples. 
Table 13. Selected Non-Radiochemical Analyses on CWT Samples

\begin{tabular}{|c|c|c|c|c|c|c|}
\hline Sample & $\begin{array}{c}\text { Na } \\
(\mathbf{m g} / \mathbf{L})\end{array}$ & $\begin{array}{c}\mathbf{B} \\
(\mathbf{m g} / \mathbf{L})\end{array}$ & $\begin{array}{c}\text { Modifier } \\
\mathbf{( m g / L )}\end{array}$ & $\begin{array}{c}\text { Density } \\
(\mathbf{g} / \mathbf{m L})\end{array}$ & $\mathbf{p H}$ & $\begin{array}{c}\text { Free } \mathbf{~ O H} \\
\mathbf{( M )}\end{array}$ \\
\hline Prelim & NA & NA & $<10$ & NA & 14 & NA \\
\hline Microbatch 1 & NA & NA & NA & NA & 12 & NA \\
\hline Microbatch 2 & NA & NA & NA & NA & 12 & NA \\
\hline Microbatch 3 & NA & NA & NA & NA & 12 & NA \\
\hline Microbatch 4 & 833 & 1.28 & NA & 1.00 & 12 & 0.0209 \\
\hline Microbatch 5 & NA & NA & NA & NA & 12 & NA \\
\hline Microbatch 6a & NA & NA & NA & NA & 12 & NA \\
\hline Microbatch 6b & NA & NA & NA & NA & 12 & NA \\
\hline Microbatch 6c & NA & NA & NA & NA & 12 & NA \\
\hline
\end{tabular}

The analytical uncertainty on the sodium and Free $\mathrm{OH}$ measurements are $10 \%$. The $\mathrm{pH}$ paper measurements are typically good for $\pm 1 \mathrm{pH}$ unit, although discrepancies between $\mathrm{pH}$ paper and $\mathrm{pH}$ probe measurements have been noted. Density results from the average of replicate volumetric trials typically have a percentage standard deviation of $<1 \%$ between each value and the average. It is important to note that the MCU facility was expected to completely replenish the CWT between microbatches.

In theory, the CWT samples would have a starting sodium concentration of $690 \mathrm{mg} / \mathrm{L}$, a free hydroxide concentration of $0.03 \mathrm{M}(0.03 \mathrm{M} \mathrm{NaOH})$, a density of $\sim 1.00$, and a $\mathrm{pH}$ of $\sim 12$. As a whole the results indicate that the caustic wash is somewhat depleted in free hydroxide and slightly elevated in sodium, possibly from deposition of sodium from the solvent. Other than the Prelim sample $\mathrm{pH}$ of 14 , the $\mathrm{pH}$ results are as expected. The high $\mathrm{pH}$ noted in the Prelim sample may be related to the superwash of the solvent in the wash contactors. The superwash used $0.3 \mathrm{M} \mathrm{NaOH}$, and residual material $0.3 \mathrm{M} \mathrm{NaOH}$ would increase the $\mathrm{pH}$.

The Modifier analysis (by HPLC) was a check to ensure there was no selective depletion of this material from the solvent.

In addition to the HPLC analysis of a CWT sample, a SVOA analysis was performed on the Preliminary CWT sample as a general scan for any organics. See Table 14. 


\section{Table 14. SVOA Analysis of the Preliminary CWT Sample}

\begin{tabular}{|c|c|}
\hline Analyte & Concentration (mg/L) \\
\hline Modifier & 5.9 \\
\hline sec-butyl phenol & 2.4 \\
\hline$\alpha, \alpha$-dimethylbenzyl alcohol & 3.3 \\
\hline$\alpha$-methyl styrene & 0.84 \\
\hline
\end{tabular}

The analytical uncertainty for all results is $20 \%$.

The presence of small concentrations of Modifier, or its decomposition product sec-butyl phenol are not matters for concern. The Modifier is known to have a limited $(\sim 25 \mathrm{mg} / \mathrm{L})$ solubility in the previous strip acid $(0.001 \mathrm{M}$ nitric acid), so it is not surprising a small concentration is evident in the CWT. SRNL does not normally note the presence of the Modifier or the sec-butyl phenol, and the presence of these materials are possibly due to the preceding solvent superwash.

The other two compounds, $\alpha, \alpha$-dimethylbenzyl alcohol and $\alpha$-methyl styrene were seen at very low concentrations and low spectrum match factors. The latter two compounds (red text in Table 14) have no apparent relationship to the MCU solvent or its possible breakdown products. ${ }^{\text {xii,xiii }}$ Previous documents from SRNL have analyzed CWT samples, or caustic feed, and found similar types of compounds. ${ }^{\mathrm{xiv}, \mathrm{xv}}$ More recently, a Tank $50 \mathrm{H}$ SVOA sample noted the presence of a number of organic compounds at the $6-7 \mathrm{mg} / \mathrm{L}$ range. After further investigation (which is still ongoing), it is likely that the presence of those compounds were an artifact of sample preparation in the SVOA analyses. ${ }^{\text {xvi }}$

\subsection{SHT Sample Results}

The SHT samples comprised the bulk of the analyses performed at SRNL. SVOA (IsoparTM L, Modifier), HPLC (Modifier, BOBCalix, MAXCalix), TOA (TOA), NMR (Isopar $^{\mathrm{TM}}$ L, Modifier, MAXCalix, TiDG), FTIR (Isopar ${ }^{\mathrm{TM}} \mathrm{L}$, Modifier), TiDG titration (TiDG) and density were all the methods used, providing at least 2 different measurements in most cases. Please note that while SRNL has confidence in the NMR results, this method is still in development.

The results of all the measurements are reported in Table 15. In addition, the target concentrations of the components and the density from a reference sample are provided for comparison. In the case of the TiDG titration result, the analysis requires the TiDG to be in the freebase form. In order to validly compare to the reference material, which is prepared as the TiDG $\cdot \mathrm{HCl}$ salt, all the TiDG titration results are converted to the $\mathrm{TiDG} \cdot \mathrm{HCl}$ molecular weight. 
The Microbatch 2a FTIR and NMR results noted the presence of an unusual amount of water, which is likely to increase the effective analytical uncertainty for those two measurements. The high water content is most likely related to sample preparation and not a reflection of a process upset.

The density results show a larger than predicted variation in certain samples. This is considered to be due to recent difficulties in density sample preparation. SRNL is taking steps to improve the density measurements. 
SRNL-STI-2014-00101

Revision 0

Table 15. All Analyses for SHT Samples

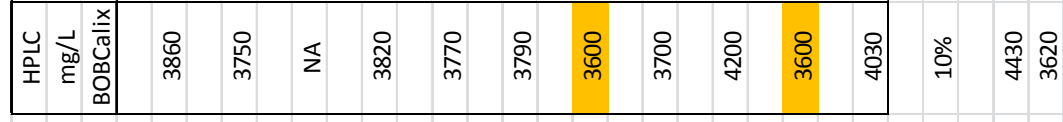

\begin{tabular}{|c|c|c|c|c|c|c|c|c|c|c|c|c|c|}
\hline 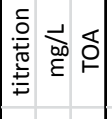 & đ্ర & $\stackrel{0}{0}$ & $\underline{q}$ & $\stackrel{\infty}{\sigma}$ & $\stackrel{m}{f}$ & $g$ & 点 & ஜु & $\stackrel{\infty}{f}$ & $\stackrel{q}{q}$ & ஜ & ఏి & $\stackrel{થ}{\vartheta}$ \\
\hline 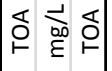 & in & ৪ & 의 & ติ & i & $\underset{u}{\infty}$ & 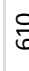 & 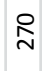 & జ్లి & g & & ذें & $\mathscr{ర}$ \\
\hline
\end{tabular}

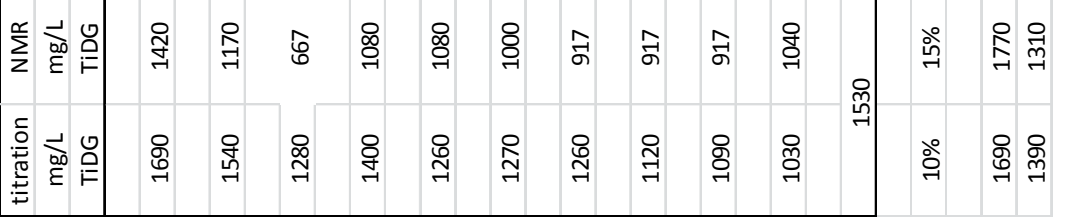

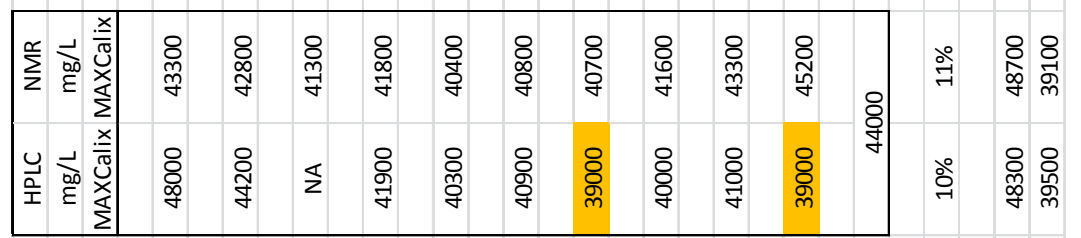

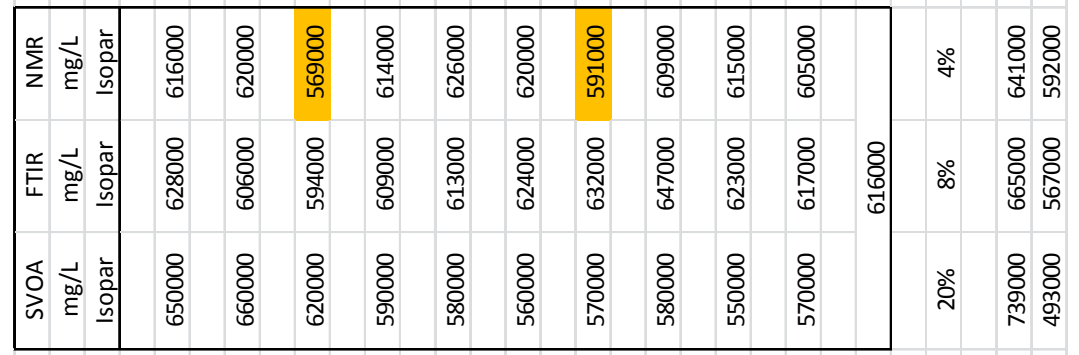

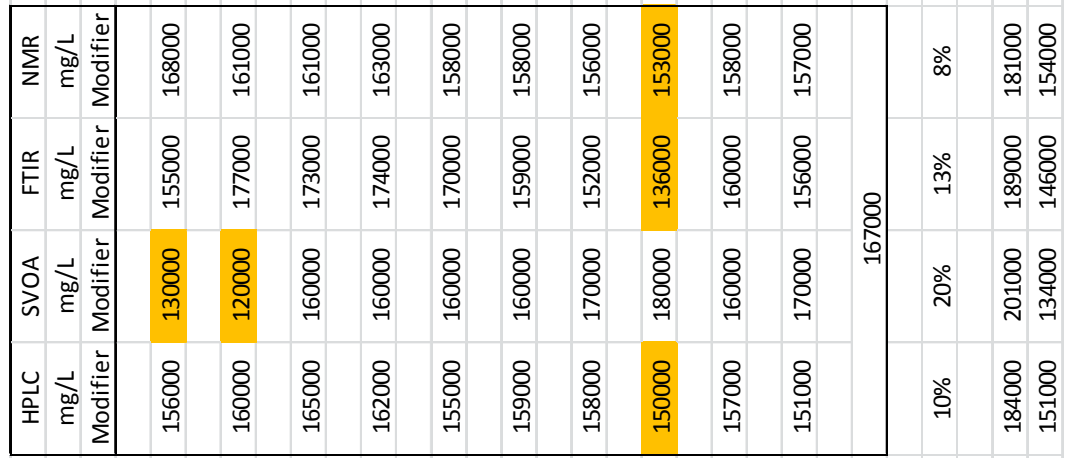

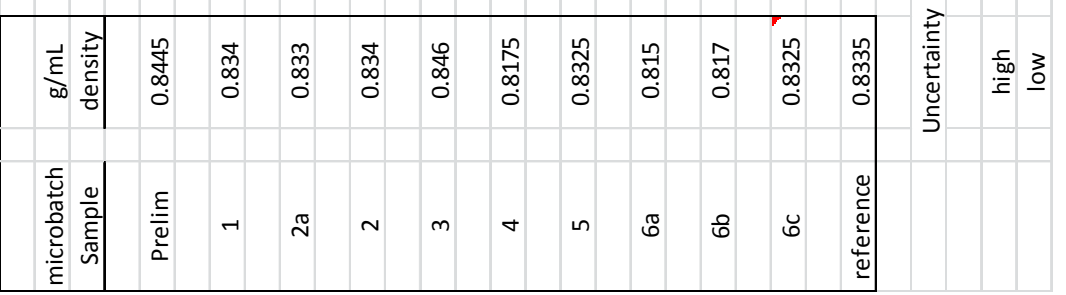


The analytical uncertainty of each measurement is listed below each column. The analytical uncertainties vary between 4 and $20 \%$, depending on the particular method. In addition, two more rows of values are listed, below the analytical uncertainties. The "high" and "low" values are derived from the reference values, with the associated analytical uncertainty factored in, to generate a range. For example, for a reference Modifier value of $167000 \mathrm{mg} / \mathrm{L}$, a HPLC measurement gives a range of 151000 to $184000 \mathrm{mg} / \mathrm{L}$. In this case, a HPLC result that lies within this range, is within the analytical uncertainty of the reference value, and can be declared to be statistically the same as the reference value. In other words, that analysis indicates the analyte is at nominal concentration.

With such a large set of data, it is more productive to examine the data set for trends rather than attempting to deconvolute each analysis against all the others. It is better to examine the individual results of each analysis and compare to the "high"-"low" range of values discussed in the paragraph above. From these comparisons, we can derive the following conclusions:

- The TiDG is being depleted at an appreciable rate. The Microbatch 6c sample indicates a TiDG concentration $\sim 65 \%$ of the reference value. This is similar to the pattern of depletion for TOA that has been observed with the BOBCalix solvent operations. ${ }^{\text {xvii }}$ However, in the same set of samples, the TOA has only barely depleted to a statistically significant degree; $84 \%$ of the reference value (from the titration data). From this comparison it would appear that the TiDG could deplete at a faster rate than the TOA did in previous operations. Recent ORNL studies corroborate this general behavior. ${ }^{\text {xviii }}$

- Both the MAXCalix and BOBCalix are within the expected range of concentrations, with the exception of four results (highlighted in Table 15), which case both values are just lower $(\sim 11 \%)$ than the "low" value in the range. As all of these results are from the HPLC, it is possible that method is showing a slight low bias on the analyses.

- Of the 40 Modifier analyses, only five samples results (highlighted in Table 15) are statistically different (lower than) from the reference value. Furthermore, three of those five corresponded to a single sample (6a).

- Of the 30 Isopar ${ }^{\mathrm{TM}} \mathrm{L}$ analyses, only two sample results from the NMR (highlighted in Table 15) are statistically different from the reference value. This is probably due to the very small analytical uncertainty $(4 \%)$ of the NMR, or due to small variations from the addition of Isopar ${ }^{\mathrm{TM}} \mathrm{L}$ at several points during the Demonstration run.

Given the relatively small amount of time and material that was processed, the solvent should not undergo any large changes in composition, with the exception of the Isopar $^{\mathrm{TM}} \mathrm{L}$, TOA and TiDG, which are anticipated to deplete more rapidly. From the data set as a whole, we can say that the solvent is at nominal composition and has held up 
well so far to processing/radiolysis decay, with the excepting TOA and TiDG. There are no real discernable trends in the solvent. Microbatch 5 and 6a samples have a slight low bias in some of their measurements, and this is likely due to sample preparation as opposed to actual changes in the solvent.

Upon consideration, the $20 \%$ analytical uncertainty of the SVOA measurement gives limited utility to this analytical method. Given the large "acceptable" value the SVOA and the availability of alternate methods, consideration should be given to no longer relying on SVOA. However, SVOA should still be used to examine samples for trace organic impurities on a quarterly basis.

\subsubsection{Consideration of the TiDG Depletion Rate}

Of all the components in the solvent, only the TOA and the TiDG show accelerated depletion. ${ }^{\Pi}$ For the TOA, the depletion is well known and has been addressed during processing. In the NGS or Blend solvent, the TOA is essentially a bystander, and there are no plans to add further TOA to the MCU system. In the case of the TiDG, the depletion must be considered. In order to forecast the demand for further TiDG additions to the system, the depletion rates are calculated below.

The depletion rate can be examined in two different ways. First, the rate can be on a time basis; $\mathrm{mg} / \mathrm{L} /$ day. The depletion rate on a volume of processed material $(\mathrm{mg} / \mathrm{L} / \mathrm{gallon}$ of feed) is also a useful rate to consider. Examination of both derived rates can potentially provide insight into the reason for the TiDG depletion. For example, if the TiDG is decomposing due to a chemical reaction with the salt solution feed or partitioning into the aqueous phases during processing, then the rate in $[\mathrm{mg} / \mathrm{L} /$ gallon of feed] is the more relevant rate. On the other hand, if the TiDG is chemically decomposing over time, then the rate in $[\mathrm{mg} / \mathrm{L} /$ day $]$ is more relevant.

From the MCU data set, it is possible to extract both of the cumulative loss rates (Table 16). At this time, no attempt has been made to factor in the effect of temperature, so these rates are not refined. SRNL is in the process of further analyzing the data to forecast the TiDG demand.

\footnotetext{
${ }^{\Pi}$ Isopar is known to evaporate; therefore, the MCU facility evaluates the need for an Isopar addition monthly.
} 
Table 16. TiDG Loss Rates

\begin{tabular}{|c|c|c|c|}
\hline Sample & TiDG*HCl (mg/L) & Loss (mg/L/day) & Loss (mg/L/gal) \\
\hline Prelim & 1690 & NA & NA \\
\hline Microbatch 1 & 1540 & 28 & 0.031 \\
\hline Microbatch 2a & 1280 & 40 & 0.042 \\
\hline Microbatch 2 & 1400 & 18 & 0.030 \\
\hline Microbatch 3 & 1260 & 17 & 0.030 \\
\hline Microbatch 4 & 1270 & 14 & 0.023 \\
\hline Microbatch 5 & 1260 & 12 & 0.019 \\
\hline Microbatch 6a & 1120 & 12 & 0.022 \\
\hline Microbatch 6b & 1090 & 11 & 0.021 \\
\hline Microbatch 6c & 1030 & 11 & 0.020 \\
\hline
\end{tabular}

\subsection{2 ${ }^{137}$ Cs in the SHT samples}

The SHT samples were also analyzed for ${ }^{137} \mathrm{Cs}$ content. This gives an indirect indication of stripping performance. See Table 17.

Table 17. ${ }^{137} \mathrm{Cs}$ in the SHT Samples

\begin{tabular}{|c|c|}
\hline Sample & $\left.{ }^{\mathbf{1 3 7}} \mathbf{C s} \mathbf{( d p m} / \mathbf{m L}\right)$ \\
\hline Prelim & $6.85 \mathrm{E}+05$ \\
\hline Microbatch 1 & $3.44 \mathrm{E}+04$ \\
\hline Microbatch 2a & $1.18 \mathrm{E}+05$ \\
\hline Microbatch 2 & $3.54 \mathrm{E}+04$ \\
\hline Microbatch 3 & $2.56 \mathrm{E}+04$ \\
\hline Microbatch 4 & $3.52 \mathrm{E}+04$ \\
\hline Microbatch 5 & $3.24 \mathrm{E}+04$ \\
\hline Microbatch 6a & $2.28 \mathrm{E}+04$ \\
\hline Microbatch 6b & $2.66 \mathrm{E}+04$ \\
\hline Microbatch 6c & $3.31 \mathrm{E}+04$ \\
\hline
\end{tabular}

The analytical uncertainty is $5 \%$ for each sample.

Over the length of the Demonstration, the ${ }^{137} \mathrm{Cs}$ in the SHT samples is down to about an order of magnitude less than the previous SHT samples during the use of the BOBCalix solvent. ${ }^{\text {ix }}$ The Macrobatch 2a sample result seems out of the pattern and this may be due 
to the mechanical issue experienced during that microbatch. As the calix concentration in the Blend Solvent is 7 fold higher than with the BOBCalix solvent, this means that the stripping performance is much improved over the BOBCalix solvent.

\subsection{Strip Feed Sample Results}

With the observation of elevated $\mathrm{pH}$ values in the SEHT samples (section 3.1.3), two samples (Microbatch 5, 6c) of the strip acid feed were analyzed. ICPES, TIC/TOC and $\mathrm{pH}$ were measured for both samples. The results are reported in Table 18.

Table 18. Results of Analyses of Microbatch 5 and 6a Strip Feed

\begin{tabular}{|c|c|c|c|c|}
\hline Sample & B (mg/L) & TIC (mg/L) & TOC (mg/L) & pH \\
\hline Microbatch 5 & 104 & 11.9 & $<10$ & 6.3 \\
\hline Microbatch 6c & 99.7 & 6.20 & $<10$ & 5.9 \\
\hline
\end{tabular}

The analytical uncertainty for the boron and TIC/TOC results are $10 \%$. The uncertainty of the $\mathrm{pH}$ probe is $0.1 \mathrm{pH}$ units.

The boron result is a measure of the boric acid concentration, which for a $0.01 \mathrm{M}$ boric acid solution corresponds to $108 \mathrm{mg} / \mathrm{L}$ of boron. As with the SEHT sample, the TIC result is assumed to correspond to carbonate. These sample results then give 59.6 and 31 $\mathrm{mg} / \mathrm{L}$ of carbonate respectively.

The $\mathrm{pH}$ results can be compared to the Boron results. The Boron results indicate the boron is as expected, implying the boric acid was prepared to the specified concentration. On the other hand, when the $\mathrm{pH}$ values are converted to boric acid concentrations, concentrations of $0.3 \mathrm{mM}$ and $0.2 \mathrm{mM}$ are calculated for Microbatch 5 and $6 \mathrm{c}$, respectively. This in turn implies one of several conditions:

- the $\mathrm{pH}$ measurement is biased high in these solutions

- the boric acid was not prepared as a pure acid

- there is some impurity present that is biasing the $\mathrm{pH}$ measurement high

The $\mathrm{pH}$ probes are calibrated at $3 \mathrm{pH}$ values before use $(4,7,10)$ so the first condition is unlikely. The ICPES of the strip feeds show less than detectable concentrations of the common cations $(\mathrm{Na}, \mathrm{K}, \mathrm{Ca})$ that would indicate an impurity; making the second condition unlikely.

The only plausible reason for the high $\mathrm{pH}$ in the strip feed is the inclusion of a very small amount of bicarbonate/carbonate impurity in the feed, which will drive the $\mathrm{pH}$ upwards. This may be further counter-balanced by a very small quantity of absorbed $\mathrm{CO}_{2}$, which 
would drive the $\mathrm{pH}$ down. The OLI model suggests that the small quantity of TIC (which can be any or both of $\mathrm{CO}_{2}$ or $\mathrm{HCO}_{3}{ }^{-}$) could theoretically provide the measured $\mathrm{pH}$ result. SRNL recommends, as part of future work, monitoring the $\mathrm{pH}$ a solution of boric acid purged with $\mathrm{CO}_{2}$ to examine this theory. ${ }^{\text {vii }}$

\subsection{Scrub Feed Sample Results}

With the observation of elevated $\mathrm{pH}$ values in the SEHT samples (section 3.1.3), one sample (Microbatch 6c) of the scrub caustic feed was analyzed. ICPES, TIC/TOC and $\mathrm{pH}$ were measured for the sample. The results are reported in Table 19.

Table 19. Results of Analyses of Microbatch 6c Scrub Feed

\begin{tabular}{|c|c|c|c|c|}
\hline Sample & Na (mg/L) & TIC (mg/L) & TOC (mg/L) & pH \\
\hline Microbatch 6c & 610 & 122 & $<4$ & 11.6 \\
\hline
\end{tabular}

The analytical uncertainty for the sodium and TIC/TOC results are $10 \%$. The uncertainty of the $\mathrm{pH}$ probe is $0.1 \mathrm{pH}$ units.

The $\mathrm{pH}$ result, when converted to Free Hydroxide, gives a value of $4 \mathrm{mM}$, where in theory it should be $25 \mathrm{mM}$. The sodium result of $610 \mathrm{mg} / \mathrm{L}$ converts to $0.0265 \mathrm{M}$, which is where $0.025 \mathrm{M} \mathrm{NaOH}$ should be. The scrub feed is subject to $\mathrm{CO}_{2}$ uptake from the atmosphere, which will convert hydroxide into bicarbonate. If further hydroxide is still available, this can react with the bicarbonate to produce carbonate. SRNL performed a run of the OLI model of a $0.0265 \mathrm{M} \mathrm{NaOH}$ solution, with enough $\mathrm{CO}_{2}$ to account for the TIC result. OLI predicts a $\mathrm{pH}$ of 11.7 , which is very close to the measured 11.6 value.

\subsection{Comparison between F/H and SRNL Sample Results}

In a selected number of cases, both $\mathrm{F} / \mathrm{H}$ lab and SRNL have performed analyses on the same Microbatch sample. It is appropriate to compare these results to ensure neither lab is suffering from a particular bias. The largest body of data for comparison is the ${ }^{137} \mathrm{Cs}$ data. Samples of the CWT, DSSHT and SEHT were sent to both SRNL and F/H lab, leading to 12 sample overlaps. See Table 20. "mb" is shorthand for "Microbatch" 
Table 20. Comparison of ${ }^{137}$ Cs Results between SRNL and F/H Lab

\begin{tabular}{|c|c|c|}
\hline Sample & $\begin{array}{c}{ }^{137} \mathrm{Cs}(\mathrm{SRNL}) \\
(\mathrm{dpm} / \mathrm{mL})\end{array}$ & $\begin{array}{c}{ }^{137} \mathrm{Cs}(\mathrm{F} / \mathrm{H}) \\
(\mathrm{dpm} / \mathrm{mL})\end{array}$ \\
\hline CWT mb1 & $6.62 \mathrm{E}+02$ & $1.24 \mathrm{E}+03(18.3 \%)$ \\
\hline CWT mb2 & $7.67 \mathrm{E}+02$ & $1.35 \mathrm{E}+03(25.5 \%)$ \\
\hline CWT mb3 & $8.60 \mathrm{E}+02$ & $1.13 \mathrm{E}+03(39.2 \%)$ \\
\hline CWT mb4 & $1.22 \mathrm{E}+02$ & $8.94 \mathrm{E}+02(33.9 \%)$ \\
\hline CWT mb5 & $5.65 \mathrm{E}+02$ & $1.10 \mathrm{E}+03(32.8 \%)$ \\
\hline CWT mb6b & $4.24 \mathrm{E}+02$ & $6.72 \mathrm{E}+02(8.62 \%)$ \\
\hline CWT mb6c & $7.80 \mathrm{E}+02$ & $7.95 \mathrm{E}+02(20.6 \%)$ \\
\hline DSSHT mb1 & $1.35 \mathrm{E}+06$ & $1.21 \mathrm{E}+06$ \\
\hline SEHT mb1 & $1.55 \mathrm{E}+08$ & $3.30 \mathrm{E}+08$ \\
\hline SEHT mb6b & $1.09 \mathrm{E}+09$ & $7.51 \mathrm{E}+08$ \\
\hline
\end{tabular}

The analytical uncertainty for $\mathrm{F} / \mathrm{H}$ lab is $12 \%$, where as SRNL results are 5\%, except for the SRNL CWT mb4 result, which is $8.46 \%$. The $\mathrm{F} / \mathrm{H}$ results for the CWT samples are averages of multiple sample results. For these results the value in parentheses are the relative standard deviation (RSD).

In the most recent comparison of past SRNL and $\mathrm{F} / \mathrm{H}$ lab results, ${ }^{\text {iii }}$ it was found that the DSSHT results differed by an average of $\sim 7 \%$ and the SEHT results differed by an average of $\sim 11 \%$. Given this history of overall corroboration, it is surprising to see such a lack of corroboration in these comparisons. However, an examination of the CWT results from $\mathrm{F} / \mathrm{H}$ lab provided some insight. The $\mathrm{F} / \mathrm{H}$ lab $\mathrm{CWT}$ sample results are averages of multiple samples pulled within each microbatch. The large relative standard deviation indicates that even during a single microbatch, there are wide swings in the sample results. This is probably due to the system not being at equilibrium, and therefore, there is a high degree of time-dependence on when the sample is pulled.

Other than the ${ }^{137}$ Cs results, there was a single Free Hydroxide measurement. See Table 21.

Table 21. Free Hydroxide Results for Duplicate SRNL and F/H Samples

\begin{tabular}{|c|c|c|}
\hline Sample & Free OH (SRNL) M & Free OH (F/H) M \\
\hline CWT microbatch4 & 0.0209 & 0.0244 \\
\hline
\end{tabular}


The analytical uncertainty for the Free $\mathrm{OH}$ is $8 \%$ for $\mathrm{F} / \mathrm{H}$ lab and $10 \%$ for SRNL. The crosscheck of the Free Hydroxide shows that both labs are giving the same effective results.

\subsection{Brief Discussion of the Decontamination and Concentration Factors}

While a detailed examination of the cesium removal performance is beyond the scope of this document, it is appropriate to briefly discuss some of the more obvious results. The Decontamination Factor (DF) is defined as the ${ }^{137} \mathrm{Cs}$ activity in the Tank $49 \mathrm{H}$ feed solution, divided by the ${ }^{137} \mathrm{Cs}$ activity in the DSSHT sample. The Concentration Factor (CF) is defined as the ${ }^{137} \mathrm{Cs}$ activity in the SEHT sample divided by the ${ }^{137}$ Cs activity in the Tank $49 \mathrm{H}$ feed solution. The higher the DF, the greater the decontamination in the DSSHT sample. This value has no upper bound. The CF has a theoretical maximum of 15. Table 22 shows the calculated DF and CF values, using the ${ }^{137} \mathrm{Cs}$ activities from each sample, as well as the Tank $49 \mathrm{H}$ feed value $(1.30 \mathrm{E}+08 \mathrm{dpm} / \mathrm{mL})$. For the sake of

consistency, in cases where there are ${ }^{137} \mathrm{Cs}$ results from both SRNL and F/H lab, the F/H value is used.

Table 22. DF and CF Values for Demonstration Plan Samples

\begin{tabular}{|ccccc|}
\hline \multirow{2}{*}{ microbatch } & \multicolumn{2}{c}{ dpm/mL } & \multirow{2}{*}{ DF } & \multirow{2}{*}{ CF } \\
& DSSHT & SEHT & & \\
\hline prelim & $9.68 \mathrm{E}+05$ & $6.28 \mathrm{E}+07$ & $1.34 \mathrm{E}+02$ & $4.83 \mathrm{E}-01$ \\
1 & $1.21 \mathrm{E}+06$ & $3.30 \mathrm{E}+08$ & $1.08 \mathrm{E}+02$ & $2.54 \mathrm{E}+00$ \\
2 & $5.73 \mathrm{E}+05$ & $8.39 \mathrm{E}+08$ & $2.27 \mathrm{E}+02$ & $6.45 \mathrm{E}+00$ \\
3 & $8.27 \mathrm{E}+04$ & $1.15 \mathrm{E}+09$ & $1.57 \mathrm{E}+03$ & $8.84 \mathrm{E}+00$ \\
4 & $9.44 \mathrm{E}+04$ & $1.34 \mathrm{E}+09$ & $1.38 \mathrm{E}+03$ & $1.03 \mathrm{E}+01$ \\
5 & $7.10 \mathrm{E}+04$ & $1.74 \mathrm{E}+09$ & $1.81 \mathrm{E}+03$ & $1.34 \mathrm{E}+01$ \\
$6 \mathrm{a}$ & $8.45 \mathrm{E}+04$ & $1.65 \mathrm{E}+09$ & $1.53 \mathrm{E}+03$ & $1.27 \mathrm{E}+01$ \\
$6 \mathrm{~b}$ & $7.68 \mathrm{E}+04$ & $7.51 \mathrm{E}+08$ & $1.69 \mathrm{E}+03$ & $5.78 \mathrm{E}+00$ \\
$6 \mathrm{c}$ & $7.68 \mathrm{E}+04$ & $8.04 \mathrm{E}+08$ & $1.69 \mathrm{E}+03$ & $6.18 \mathrm{E}+00$ \\
\hline
\end{tabular}

The analytical uncertainty on each ${ }^{137} \mathrm{Cs}$ measurement is $12 \%$.

Given that the process started with residual flush material, which was worked off over time, the DF and CF should only be considered as a starting point.

The DF and CF value show a general trend - as the Demonstration continues, the DF values increase, to a maximum of $\sim 1700$. The $\mathrm{CF}$ attains a maximum of 13.4 , but then declines. See Figure 1. The decline is a result of excess strip acid being added to the 
SEHT and SE decanter due the failure of the strip feed flow meter at the end of Microbatch $6 \mathrm{a}$ and continuing into Microbatches $6 \mathrm{~b}$ and $6 \mathrm{c}$.

Figure 1. Concentration Factor over the Range of Samples

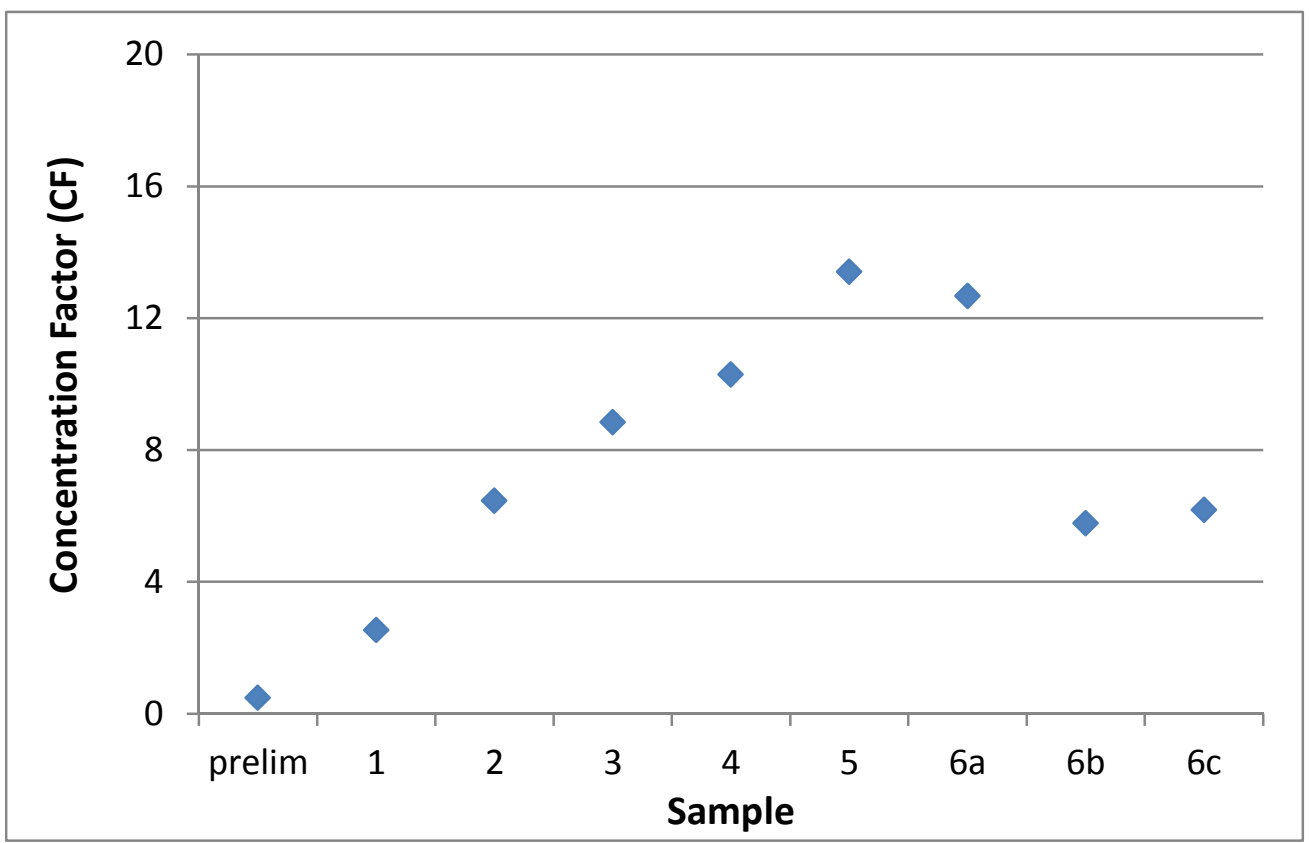

\subsection{Conclusions}

SRNL and F/H lab analyzed a large collection of samples throughout the Demonstration Plan to provide evidence as to the processability of the Blend Solvent at MCU. Samples of each of the outputs from MCU (SHT, CWT, DSSHT, and SEHT) were analyzed by multiple methods. From these analyses the following conclusions can be made on each of the outputs.

- SHT: The solvent behaved as expected, with no bulk changes in the composition over time, with the exception of the TOA and TiDG. The TiDG depletion is higher than expected, and consideration must be taken on the required rate of replenishment. Monthly sampling of the SHT is warranted. If possible, additional SHT samples for TiDG analysis (only) would help SRNL refine the TiDG degradation model.

- CWT: The CWT samples show the expected behavior in terms of bulk chemistry. The ${ }^{137} \mathrm{Cs}$ deposited into the CWT varies somewhat, but generally appears to be 
lower than during operations with the BOBCalix solvent. While a few minor organic components were noted to be present in the Preliminary sample, at this time these are thought to be artifacts of the sample preparation or may be due to the preceding solvent superwash.

- DSSHT: The DSSHT samples show the predicted bulk chemistry, although they point towards significant dilution at the front end of the Demonstration. The ${ }^{137} \mathrm{Cs}$ levels in the DSSHT are much lower than during the BOBCalix operations, which is the expected observation.

- SEHT: The SEHT samples represent the most different output of all four of the outputs from MCU. While the bulk chemistry is as expected, something is causing the $\mathrm{pH}$ of the SEHT to be higher than what would be predicted from a pure stream of $0.01 \mathrm{M}$ boric acid. There are several possible different reasons for this, and SRNL is in the process of investigating. Other than the $\mathrm{pH}$ issue, the SEHT is as predicted.

The DF and CF values are generally showing the expected trends (increased removal). The data set is limited, and as time progresses in Sample and Send mode operations, additional information will become available to make a longer term prediction of the ultimate cesium decontamination.

SRNL also performed an abbreviated set of analyses on the scrub and strip feed solutions. These were shown to be as expected, although there is evidence that both the strip feed and scrub feed contain small quantities of carbonate or bicarbonate.

Taken as a whole, the Demonstration Plan samples indicate that the MCU system, with the Blend Solvent, is operating as expected with the exception of the SEHT pH trending higher than expected, with minor issues as previously noted. SRNL is in the process of investigating the cause of the elevated $\mathrm{pH}$.

\subsection{Path Forward}

Once the Demonstration Plan is complete, MCU will be operating in a Sample and Send mode of operations in which MCU operations is expected to pull monthly SHT, CWT, SEHT and DSSHT samples for SRNL. Ideally these samples should all be pulled at the same time, or as close as possible. This will enable SRNL to provide the most accurate analysis of MCU operations.

In regards to cesium removal, the data set is limited, and as time progresses in normal Sample and Send mode operations, enough information will be available to make a longer term prediction of ultimate cesium decontamination. 
The most important consideration at this time is the depletion of the TiDG. The depletion should be carefully monitored to ensure adequate stocks of this material are available for addition to MCU.

Further SRNL suggests the following lessons are related to the analysis of the SHT samples. Based upon the large matrix of SHT sample results, SRNL recommends the following:

- Move density measurements to outside of the cells where the best precision can be obtained.

- Delete the SVOA measurement of Isopar ${ }^{\mathrm{TM}} \mathrm{L}$ and Modifier. Instead, establish the Isopar ${ }^{\mathrm{TM}} \mathrm{L}$ and Modifier relationship to density. The nominally more accurate density measurement will provide a better understanding of the concentration of these 2 largest components of the solvent.

- Delete the TOA measurement as there will be no further additions.

- Delete the BOBCalix measurement as it is no longer of concern.

- Improve and qualify the FTIR method for general analytical use. This method show great promise in SHT analyses.

- Analyze CWT samples with NMR to detect decomposition products.

- SHT samples should be taken at monthly intervals. If possible, additional SHT samples for TiDG analysis (only) would help SRNL refine the TiDG degradation model. 


\subsection{References}

${ }^{i}$ E. Ketusky, "Recommended Quantities if Solvent Constituents for Next Generation Solvent (NGS)", SRR-SPT-2012-00039, November 7, 2012.

ii A. G. Garrison, "Salt Disposition Project (SDP) Next Generation Solvent (NGS) Demonstration Plan“, SRR-SPT-2013-00033, December 12, 2013.

iii T. B. Peters, "Results of Routine Strip Effluent Hold Tank, Decontaminated Salt Solution Hold Tank, Caustic Wash Tank and Caustic Storage Tank Samples from Modular Caustic-Side Solvent Extraction Unit during Macrobatch 6 Operations", SRNL-STI-2014-00672, January 2014.

${ }^{\text {iv }}$ J. W. Ray, "Waste Acceptance Criteria for Sludge, ARP and MCU Process Transfers to 512-S and DWPF", X-DS-G-00008, Rev. 13, December 202013.

${ }^{v}$ T. B. Peters. S. D. Fink, "Consideration of the Strip Effluent (SE) pH and Sodium Content", SRNLL3100-2014-00028, February 20, 2014.

${ }^{v i}$ D. P. Lambert, "Recommended Strip Effluent pH Limits for New Generation Solvent", SRNL-L31002014-0013, January 23, 2014.

${ }^{v i i}$ Q. L. Nguyen, "Determine causes for the increase in the strip $\mathrm{pH}$ and maximmum bounding sodium value in SEHT”, X-TTR-H-00036, February 5, 2014.

viii T. B. Peters, M. S. Hay, "Initial Analysis of Strip Effluent and Strip Feed Samples”, SRNL-L3100-201400012, January 21, 2014.

${ }^{i x}$ J. W. Ray, "Waste Acceptance Criteria for Sludge, ARP and MCU Process Transfers to 512-S and DWPF", X-DS-G-00008, Rev. 14, January 2014.

${ }^{x}$ T. B. Peters, S. D. Fink, "Results of Routine Strip Effluent Hold Tank, Decontaminated Salt Solution Hold Tank, Caustic Wash Tank and Caustic Storage Tank Samples from Modular Caustic-Side Solvent Extraction Unit during Macrobatch 4 Operations", SRNL-STI-2012-00430,October 2012.

${ }^{x i}$ T. B. Peters, A. L. Washington II, "Sample Results from the Interim Salt Disposition Program Macrobatch 7 Tank 21H Qualification Samples”, SRNL-STI-2013-00347, August 2013.

${ }^{\text {xii }}$ F. F. Fondeur, D. T. Hobbs, S. D. Fink, "Thermal and Spectroscopic Analyses of Caustic Side Solvent Extraction (CSSX) Solvent Contacted with 16 Molar and 8 Molar Nitric Acid”, WSRC-TR-2007-00212, July 12, 2007.

xiii F. F. Fondeur, S. D. Fink, "Thermal and Spectroscopic Analyses of Next Generation Caustic Side Solvent Extraction Solvent (CSSX) Contacted with 3, 8, and 16 Molar Nitric Acid", SRNL-STI-201100576, September 29, 2011.

${ }^{\text {xiv }}$ T. B. Peters, F. F. Fondeur, S. D. Fink, "Results from Solvent Hold Tank and Other Samples during March 2010 Outage", STNL-STI-2010-00311, January 2011.

${ }^{x v}$ F. F. Fondeur, S. D. Fink, "Characterization and Evaluation of Caustic Wash Tank and Solvent Hold Tank Samples from MCU from August to September 2011 (SHT 221-226, SHT 314-319, SHT 10351040, and CWT 817-904)", SRNL-STI-2012-00324, August 2012.

${ }^{x v i}$ S. L. Crump, “ Artifact Formation during Neutralization of Tank 50 Samples”, SRNL-L4100-2014-00001, March 3, 2014. 
${ }^{x v i i}$ T. B. Peters, A. H. Couture, "Investigation into the Rate of Trioctylamine Partitioning into the MCU Aqueous Phases", SRNL-STI-2013-00195, June 2013.

${ }^{\text {xviii }}$ B. A. Moyer, L. H. Delmau, B. D. Roach, and N. J. Williams, "Thermal Degradation of Next Generation Solvent Using Triisodecylguanidine Suppressor: Impact of Solvent Performance and Organic Content of Aqueous Effluents", ORNL-LTR-NGCSSX-020, Rev. 1, July 2013.

${ }^{\text {xix }}$ F. F. Fondeur, K. M. L. Taylor-Pashow, "Solvent Hold Tank Sample Results for MCU-13-1403/1404/1405/1406/1407/1408: Quarterly Sample from September 2013”, SRNL-STI-201300661 , November 2013. 


\section{Distribution:}

S. L. Marra, 773-A

F. M. Pennebaker 773-42A

T. B. Brown, 773-A

S. D. Fink, 773-A

C. C. Herman, 773-A

E. N. Hoffman, 999-W

D. H. McGuire, 999-W

W. R. Wilmarth, 773-A

Records Administration (EDWS)

E. A. Brass, 249-8H

T.E. Smith, 241-152H

C. J. Scherman, 241-152H

Q. L. Nguyen, 241-152H

E. J. Freed, 704-S

A. G. Garrison, 248-9H

B. A. Gifford, 704-56H

T. A. Le, 766-H

D. J. Martin, 241-152H

A. R. Shafer, 704-27S

R. H. Spires, 248-8H

C. A. Nash, 773-42A

P. R. Jackson, DOE-SR, 703-46A 